\title{
Reading Nowhere in Erewhon: Bellamy, Morris, and New Zealand
}

\author{
Dougal McNeill
}

Utopias pursue one another. It is a polemical form, proceeding by way of rewriting and echoing, each visionary's scheme getting built out of the material torn from a previous programme. Edward Bellamy's Looking Backward, an astonishing success in its own time, and rivalled only by Uncle Tom's Cabin in sales, provoked William Morris to write News from Nowhere, a report from the 'epoch of rest' doubling as a critique of Bellamy's perfected social order. News from Nowhere's initial serial publication in Commonweal, the journal of the Socialist League edited by Morris, was, in turn, as Paul O'Flinn has argued, an intervention into the League's politics, with Morris' unnamed hero 'damning the rest for fools' (Morris 43) and arguing his case as much against the anarchist currents in the League as against Bellamy's consumerist vision. News from Nowhere, as Matthew Beaumont argues, 'sets out to realise a future state that is qualitatively different from the idealised reality evoked by some of [Morris'] contemporaries' and acts as 'an attempt to defuse the power of Looking Backward. It cancels out one promissory note with another' (69).

The 1890 s saw, in Beaumont's neat phrase, 'a veritable discursive explosion' (1) in Utopian production globally; it was in this era that the fruitjuice drinkers and sandal-wearers of Orwell's famous list were born, and their presence, in literature and politics, shaped the culture of the fin-desiècle. New Zealand was particularly receptive to the shards and fragments that flew out from this explosion, Erewhon and the 'land without strikes' having been, after all, the site itself of a great deal of utopianism. 'Utopia,' Dominic Alessio has suggested, 'was central to the nation's culture and resulted in the paradise myth emerging as one of its dominant tropes' (22). Looking Backward, Bellamy's story of an aristocratic Bostonian woken from hypnotic sleep to see his city in its cleanliness and splendour in the year 2000, ruled over by a benign but all-controlling state in command of an industrial army, enjoyed what Lyman Tower Sargent has called 'immense popularity' (171) in New Zealand. Press reports discussed the novel in 1889, 
just months after its American publication and before stock had reached New Zealand. Excerpts were published in several newspapers through 1890. There were at least three local editions, and enormous interest and sales. The Dunedin Evening Star ran a report from Braithwaite's Book Arcade on 17 $7^{\text {th }}$ April 1890: 'I have sold 5 ooo copies of this marvellous Socialistic book since I reviewed it in the Star about six months ago'; similar accounts appear in newspapers across the country. ${ }^{1}$

What then of Morris? His Utopian rejoinder travelled with Bellamy to New Zealand, certainly; Alexander Turnbull owned copies of both works, as well as keeping standing orders with Morris' Kelmscott Press. The quarrel was hardly on equal local terms, however; there were no local editions of News from Nowhere, and it gathered together nothing approaching the attention Looking Backward generated. ${ }^{2}$ Bellamy enjoyed phenomenal international success and, as Carl Guarneri has suggested, 'the generic quality of Bellamy's utopia helped it to travel well. Looking Backward's plan is universally applicable, not the product of a particular national context or socialist sect [...] there is little uniquely American about Looking Backward's programme, [and] its implementation is also not conditioned by local or national traits' (19). It is unsurprising, then, that scholars have passed to Bellamy without mentioning Morris' New Zealand reception. Something does get missed along the way, however; my purpose in this essay is to restore some sense of the Utopian competition that went on as the two works were received in New Zealand. This, in turn, offers chances to look at the more general literary culture of the period in a different way. Jane Stafford and Mark Williams' demand, in their Maoriland, that research shake off the assumptions of belatedness as 'one of the signs of provincialism' bequeathed to us by Curnow is reinforced by a consideration of Utopian energies in the period. 'Advanced trends as well as dated ones circulate through the writing of the period,' they observe. 'The centreperiphery model of empire needs to be modified to accommodate the complex cross-affiliations and influences of the period. Literary nationalism's exclusive focus on the local ignores, and even denies, the international sources of the local.' (16) Utopian literature is one of the 'international sources of the local'; reading Morris alongside Bellamy contributes to the modification Stafford and Williams call for, drawing our attention to the different ways 'literature' and the 'literary' were deployed in the period. 
Looking Backward and News from Nowhere, both international sources, were read as 'local' texts. Bellamy's 'rather remarkable work' was, for the Auckland Star's reviewer, 'written on somewhat the same lines as Sir Julius Vogel's new book [Anno Domini 20oo, or, Woman's destiny]' (9/9/89, 4). The 'impossible and utterly impracticable schemes' of the Wellington Liberal Association were, the Wairarapa Times' Wellington correspondent mocked, dreams of 'making the ideal State of New Zealand like unto Morris' ideal England as set forth in his Socialistic and Utopian romance' (19/4/93, 2). A tale from the Pall Mall Gazette, reprinted in several local papers, quoted a New Zealand employer in a hotel in Glasgow: 'it pays to make workpeople contented and happy.' He had ordered eight dozen copies of Looking Backward as he was 'so delighted with the millennium Bellamy had foreshadowed'; circulating the text was for his employees' literary edification and to boost productivity. 'Pater' a regular columnist in the Otago Witness, called Looking Backward and News from Nowhere 'books on the table of every reader interested in the advance of social events' (30/7/91, 36); their place on that local table is the focus of this essay.

\section{THE BELLAMY BOOM}

'Bellamy's little brochure is just now the rage of the hour and we are afraid to mention how many of the various editions we are told have been circulated in Auckland alone'; this was how the booksellers Wildman advertised fresh copies of Looking Backward in 1890. ${ }^{4}$ The novel sold rapidly, and quickly became a part of the colony's intellectual and cultural thought world. William Pember Reeves serialised it in the Lyttleton Times through August 1889; later that year a short story of Reeves, 'A Helpless Spectator', published in the first issue of Zealandia, could assume enough readerly familiarity with Bellamy to be studded with intertextual references. Articles by 'Pharos' (Reeves) in later issues of the Lyttleton Times expounded Bellamy's themes. ${ }^{5}$ Fictionalised responses appeared within a year of Looking Backward's first publication, with the Press serialising a 'Looking Forward' (the first of many), and all the major newspapers ran advertisements for the work through $1890 .{ }^{6}$ Described as a brilliant romance' and a 'charming book', Looking Backward's success became news in itself. Columns through 1890 speculate on Bellamy's wealth and report on his extraordinary sales abroad. The novel was dramatised and adapted for the stage; a racehorse was named after its author! ${ }^{7}$ 
The novel's reception illustrates too how the boundaries between 'literary' writing and persuasive or politically-directed prose were still porous in this period of New Zealand's literary history. Bellamy introduced his novel as both a 'romantic narrative' (3) and as a 'forecast [...] of the next stage in the industrial and social development of humanity' (195); if later readers have struggled with this, for us, generic incongruity, contemporary New Zealand readers took them in combination. It was read by literary societies and political meetings, denounced from the pulpit and defended from a Christian viewpoint. The Social Reform Association 'referred to [it] at length' during a Dunedin meeting, while 'laughter and applause' followed an ironic mention of Looking Backward at the Exhibition Mining Conference of March 1890. Public lectures and discussions of Looking Backward were organised by members of the Presbyterian Church in Ashburton, the St John's Literary Society in Wellington, the Wanganui Musical and Literary Society, the Mount Eden Young Men's Improvement Association and the Taranaki Mutual Improvement Society. Wellington Spiritualists even listened to a lecture on Looking Backward before forming their circles and beginning a séance. ${ }^{8}$ Bellamy's Utopian programme-an industrial army, state ownership, social peace-were picked up by politicians, with Mr James Allen, the Member of Parliament for Dunedin East, concluding a meeting with references to Looking Backward, while opponents of the 'half-holiday movement in Dunedin' blamed its popularity on 'Edward Bellamy's excessively stupid book.' Kate Sheppard, speaking in Christchurch in 1892, made the case for women to be treated 'as units in the industrial army,' a clear reference to Bellamy. ${ }^{9}$

Further Utopian production is the surest sign of a Utopia's generic success, and Looking Backward provoked these. 'Robinson Crusoe' published Looking Upwards; or, Nothing New in Auckland in 1892 in order to 'show how we are to reach the state pictured by Bellamy, and to show that we must go on in that direction, or back to barbarism' (7). An 'Edward Bellamy Society' published a Prospectus of New Zealand Limited in 1910. The discursive engine had started whirring; so many Utopian schemes and fancies were the result. 


\section{NEWS FROM NOWHERE AND THE MAORILAND WORKER}

Morris enjoyed nothing like this success. In the newspapers to 1945 digitised by the Papers Past collection there are over a thousand references to Bellamy and Looking Backward. ${ }^{10}$ Morris and News from Nowhere appear in just over one hundred and fifty articles. Morris' response to Bellamy did not pass unremarked-Frank Morton praised it as 'the most pleasantly expressed of all the books that attempt to sketch a possible Socialist paradise' in the Marlborough Express (6 $6^{\text {th }}$ April 1910)-but references are infrequent and advertisements few.

News from Nowhere's local reception and influence is developed primarily in the Maoriland Worker. The Worker, under both Robert Ross' and Harry Holland's editorship, ran comments on Morris' work that stressed its literary qualities as a form of political value. News from Nowhere, along with works by Charlotte Perkins Gilman, Edward Carpenter and, surprisingly, John Galsworthy, were described as books that 'would tend to develop the imaginative faculty of their readers' $\left(31^{\text {st }}\right.$ May 1912,1$)$ and thus foster 'either conscious or unconscious socialists'. Advertisements for News from Nowhere appeared in the Maoriland Worker from 1912, two years after its foundation, through to 1918. It is described either as a 'miscellaneous' item amongst Philip Joseph's 'Library of Anarchism', as 'literature for propaganda' that can help 'spread the light' or as one of the eclectic range-including Wilde, Wells, Ruskin, Debs, Kropotkin, Marx, Jack London, Alfred Noyes, Mark Twain and others-available from the Maoriland Worker Printery in Wellington. ${ }^{11}$

Strategy, political analysis and the creation of new Utopian subjectivities fuse in curious approaches to reading in the Maoriland Worker's presentation of Morris. The journal's fourth issue (December 1910) reprinted a section from the famous seventeenth chapter of News from Nowhere - 'How the Change Came,' narrating an armed insurrection and revolutionary general strike in contrast to Bellamy's smooth transfer-for reasons to do with strategy: 'the following extracts from one of the chapters in this Utopian Romance have a particular interest to New Zealanders at the present time, in view of the efforts made towards a more complete industrial organisation' (2). In other moods, however, the Worker's columnists valued Morris' work for its ability to foster a socialist outlook, to make, in other words, Utopian personalities:

We gladly welcome a new edition of this Utopian Romance by that master craftsman, William Morris. Without doubt this 'weaver of 
beautiful thoughts' played a large part in the hard spade-work of the British Socialist movement and it would ill become us if we did not keep in circulation his literary contributions which brought hope and revelations to thousands of minds struggling for a better world [...] In these days of the destruction of empires and bold experiments in organised labour, it is refreshing to read and re-read the descriptions Morris gives (through Old Hammond) of 'How the Change Came' [...] We hope that the youngsters of the movement will get News from Nowhere; it is the kind of work that creates the soul without which we cannot hope to succeed. (GTS, 'The Morrow,' $22^{\text {nd }}$ June 1921)

The cultural nationalist politics of the 1930 s will combine left-wing and international political affiliations with calls for a local culture, but what the Maoriland Worker's writers do with Morris sustains, into the 1920s, what Stafford and Williams call the 'international sources of the local' (16). His Utopia is read, in the Worker, as a form of New Zealand literature. The local practice follows that of what Stephen Yeo has identified as the public culture of education in the Victorian Left in Britain, with political meetings 'often attached to readings, providing evidence that Towards Democracy, Merrie England or News from Nowhere were gulped thirstly into the consciousness of workers, and were used as integral parts of socialist life' (29). An account by Frank Freeman of the 1913 Great Strike in Wellington frames its account by reference to News From Nowhere. 'Ye Gods!' the article begins. 'I was living for just a little while in the times of William Morris' News from Nowhere (make yourself a New Year's present of the book from The Worker office)' and, after detailing the confrontations between strikers and Massey's Cossacks, concludes:

The ending of News from Nowhere always brings a touch of sadness to me as I read. That touch was changed to a staggering blow as I passed out of the crowd. Our boys were being forced back into the Hell of Capitalism in order to be better prepared to hasten its extinction. That procession will live in the lives of everyone who took part in it. It was the greatest and grandest thing seen in Wellington during that heroic nine weeks' struggle. ( $7^{\text {th }}$ January 1914,5$)$

A parable from the $12^{\text {th }}$ August 1914 Maoriland Worker affiliates Morris with local tradition in a similar way: a boy sent home from school to prepare to play the 'Red Fed' candidate in a mock election is introduced by 'the Innocent' to political theory. 'I told him of William Morris' News from Nowhere and [the child's] face glowed with the desire of realisation. 'Wouldn't it be bosker to have Socialism now?' he inquired. 'I'm glad I'm a Socialist.' The parable ends: 'I smiled quietly and gave him News from 
Nowhere to read at his leisure' (7). The Worker did not always distinguish between fiction and other types of literature, describing Syndicalism and the Cooperative Commonwealth as belonging 'to the same class of Utopian literature as Bellamy's Looking Backward and Morris' News from Nowhere' $\left(22^{\text {nd }}\right.$ August 1913, 2). Socialist letter-writers to the 'bourgeois' newspapers offered News from Nowhere as a guide to the ideals of Socialists', noting its literary qualities but subordinating these to its pedagogical and persuasive force. ${ }^{12}$

This is literature for revolution, then; one, obvious, explanation for Morris' relative obscurity compared to Bellamy's literary dominance is to do with audience and aims. Morris' Utopia, written for publication in a revolutionary socialist newspaper in Britain, and aiming its polemical fire at debates within the radical left, appealed to a narrower readership and found a much less promising literary-cultural environment in New Zealand in which to develop. Bellamy's scheme, with its dreams of 'the prodigious increase of efficiency' (32) in the new world and its concerns for 'the opinions of the people of my class' (10), matched more easily with a wider range of social opinions and class readerships. More local Utopian energies may well have worked against Morris' reception too. His cheerful reduction of Westminster and Parliament to the 'Dung Market' (77), and his arcadian, environmentalist presentation of an England re-greened and rendered rural and unchanging ('this is not an age of inventions' 192) reads rather differently with Tinakori hill looming behind Parliament Buildings; all that countryside may, in New Zealand's still half-formed cities, have been too much for imaginative comfort. Bellamy's projections-of the 'great distributing establishments' anticipating shopping malls, a 'vast hall full of light, received not alone from the windows on all sides, but from the dome, the point of which was a hundred feet above' (60) - fitted colonial longings for city life and its sophistication. Bellamy domesticated Marx, Beaumont suggests: 'Bellamy ghosted Marx's writing in order to exorcise his spirit from contemporary socialism' (9), and this comfort gave his work greater purchase across the political spectrum than Morris' intransigently revolutionary vision.

A more properly Utopian explanation suggests itself. Morris failed, in New Zealand, to generate sufficient distance from his polemical target; his work, in provoking no local Utopian re-writing or re-coding, became assimilated by its rival. The Clarte Bookshop, in an advertising letter promoting literature to Wellington's Trades Hall in 1931, listed Morris 
alongside Bellamy as works that 'for a thorough understanding of Socialism it is hard to beat'. Another booklist two years earlier listed Looking Backward-'one of the most known and most widely read stories in the world. Entertaining, educational and convincing'-but no Morris. ${ }^{13}$ Alexander Scott, leader of the Edward Bellamy Society in the 1930s, could promote his Utopian solution without needing more than the lightest poke in Morris' direction: 'Edward Bellamy's Utopia, or vision of the future, was much more practical and sketched in much greater detail than William Morris' (3), while many commentators made no distinction between them. Walter Nash, initiating an essay competition on the theme 'what socialism is' put Bellamy on his reading list but not Morris, while the Maoriland Worker 'Post Bag' reply to 'TB' of Napier's request for reading suggestions offered: 'Blatchford's Merrie England then Britain for the British for a start. Then follow on with Bellamy's Looking Backward and Equality. Next read Karl Marx's Wages, Labour and Capital and Value, Price and Profit. When you have digested these we will recommend others. In the meantime, keep on reading The Worker.' ${ }^{14}$ An Auckland Star report of the Workers' Educational Association 'recent summer camp at Paerata' mused that 'Richard [sic] Bellamy and William Morris could have taken part in the camp, [and] would have found it a realisation of their dreams. It was like a cinematograph picture of Looking Backward or News from Nowhere' $(5 / 1 / 35,6)$. A correspondent to the Hawera and Normanby Star (27/7/94, 2) found News from Nowhere 'much better from a literary point of view, but less comprehensive': no sense of the two texts' polemical struggle with each others' visions is recorded. The Worker's one-time editor, Robert Ross, assimilated the two visions:

[in] our own times stories such as News from Nowhere and Looking Backward tremendously gripped the popular imagination and set a fashion. Most of us remembered also Caesar's Column, The Golden Bottle, The Iron Heel and When the Sleeper Wakes. Of these and some others - of all of them - none gripped, I think, like Looking Backward [...] by Edward Bellamy, though William Morris' News from Nowhere is finer in artistry and has made itself a classic. It has a beauty of conception, as of execution, that sets the whole of one's emotions blossoming. Yet Looking Backward leapt into popularity and thrilled us all. It led to the formation of Bellamy Societies for the express purpose of bringing its views into operation. It is still widely read. $(9 / 3 / 21)$

The Bellamy Societies did ensure that Looking Backward remained widely read, but their advocacy was, in the beginnings of the 'post-Maoriland' 
literary nationalism of the 1930s, at the expense of the ambiguous literarypolitical relationship the 1890 s found possible. The Society's Constitution and Rules, prepared in November 1936, mention 'the sociological works of Edward Bellamy'; Looking Backward's status as a novel was of no concern to the Society. ${ }^{15}$ Their broadcasts and publications-in the Labour Party newspaper The Standard as well as on radio-are wholly politically focussed. Its members had literary interests, to be sure-Professor von Zedlitz from Victoria University College was a prominent supporter and speaker-but these did not figure in their Utopian projects. The Depression prompted a revival of interest in Bellamy's plans, but these were sociological interests instead of Utopian ones:

In these queer times it is always interesting to discover what people are thinking, discussing, and reading. A gentleman connected with the wholesale book trade has remarked that his greatest sales over a fairly considerable recent period were of the Bible and Edward Bellamy's Looking Backward [...] Bellamy's book is credited by some as having been a powerful inspiration behind the urge for social reform and legislative experiment which followed the depression of the nineties, being particularly marked in this part of the world, Australia and New Zealand. Similar conditions seem to be producing similar reactions in men's minds, a fact which may have something to do with the demand for Looking Backward. (New Zealand Herald, 'Local Gossip', 10/6/33, 1)

The literary culture had shifted, and Bellamy's place with it; his Utopian Romance was a part of Maoriland's literature, but could not survive into New Zealand's. The Communist Party, meanwhile, had no use for the aesthetic traditions of socialism Morris represented; its growing Soviet orthodoxy through the 1930s squeezed out any political space News from Nowhere might have had in committed local reading habits. When a group of dissident Christchurch Communists, led by Elsie Locke, formed a William Morris Group in 1953, they made no mention of News from Nowhere. Morris' name was, for them, associated with visual arts and song, not political programme. ${ }^{16}$ Morris hoped his would be called 'a vision rather than a dream' (228); in Erewhon it ended up neither.

The kōtare, this journal's namesake, encourages us to look for what was hidden, and to note the unexpected or seemingly uneventful. This essay, I hope, has filled another part of the cartography of Maoriland in literature Stafford and Williams urge us to map. Tracing the prominence and the obscurity of Bellamy and Morris in New Zealand offers suggestive moments for thinking about the category of 'literature', the place of international texts 
in local imagination and rhetoric, and the networks across countries by which Utopias are generated. Who knows where the next connection might come from? Books travel in unexpected ways, after all. The last mention of News from Nowhere before the post-war period appears in an account of reading at sea. Osaka, Japan, the sailor correspondent assures the Auckland Star's readers, has the best second-hand bookshop in the world. And there he found, long out of print, his copy of News from Nowhere.

\section{WORKS CITED}

Alessio, Dominic. 'Promoting Paradise: Utopianism and National Identity in New Zealand 1870-1930'. New Zealand Journal of History . 42, 1, 2000. 22-41.

Beaumont, Matthew. Utopia Ltd: Ideologies of Social Dreaming in England 1870-1900. Chicago: Haymarket, 2009.

Beere, Wyn O. Prospectus of New Zealand Limited (Limited as to area only): a Company Not Incorporated Under the Companies Act of 1908. Wellington: Edward Bellamy Society, 1910.

Bellamy, Edward. Looking Backward 2000-1887. Ed. Matthew Beaumont. Oxford: Oxford University Press, 2007.

Davidson, Jared. Sewing Freedom: Philip Josephs, Transnationalism and Early New Zealand Anarchism. Edinburgh: AK Press, 2013.

Guarneri, Carl. ‘Edward Bellamy's Looking Backward: the International Impact of an American Socialist Utopia 1888-1945'. In Mary G. Kemperink and Willemien H. S. Roenhorst, eds. Visualizing Utopia. Leuven: Peeters, 2007.

Le Mire, Eugene. A Bibliography of William Morris. London: Oak Knoll Press and the British Library, 2006.

Morris, William. News from Nowhere and Other Writings. Ed. Clive Wilmer. Harmondsworth: Penguin, 1993.

O'Flinn, Paul. 'From the Kingdom of Necessity to the Kingdom of Freedom: Morris's News from Nowhere'. International Socialism. 2: 72, 1996. 101-12.

'Robinson Crusoe' [A. Stanford] Looking Upwards; or, Nothing New. In Two Parts. Part One: The Up Grade: from Henry George past Edward Bellamy on to Higher Intelligences. Auckland: H. Brett, 1892.

Roth, Herbert. 'Bellamy Societies of Indonesia, South Africa and New Zealand'. In Sylvia E. Bowman, ed. Edward Bellamy Abroad: An American Prophet's Influence. New York: Twayne, 1962.

Sargent, Lyman Tower. 'New Zealand Utopian Literature: A Short History'. In Pat Moloney and Kerry Taylor, ed., On the Left: Essays on Socialism in New Zealand. Dunedin: University of Otago Press, 2002. 
Scott, Alexander. The Immortal Edward Bellamy: An Introduction to the Man and His Books Looking Backward and Equality. Wellington: The Labour Bookroom, 1936.

Shor, Francis. 'The Ideological Matrix of Reform in Late-Nineteenth-Century America and New Zealand: Reading Edward Bellamy's Looking Backward'. Prospects 17: 1992, 29-58.

Stafford, Jane, and Mark Williams. Maoriland: New Zealand Literature 1872 1914. Wellington: Victoria University Press, 2006.

Yeo, Stephen. 'A New Life: the Religion of Socialism in Britain 1883-1896'. History Workshop Journal. 4: 1, 1977, 5 - 56.

\section{ENDNOTES}

${ }^{1}$ Quoted in Roth, p. 332. Roth was unhappy with the state of this chapter, writing to Francis Shor 'I always shudder when I hear that somebody has seen my contribution to the Bowman anthology, because I am ashamed of it' (1/2/90, from the Roth papers, ATL 94-106-15/18). The editor had cut details and added material without Roth's knowledge or consent. A full draft with research notes forms part of the Roth papers at the Alexander Turnbull library and, where possible, I draw on these instead of the final published chapter.

${ }^{2}$ Eugene Le Mire's Bibliography of William Morris lists no New Zealand publications for any of his works. Library holdings give some sense of the two books' different reach in New Zealand. Sir George Grey owned a copy of Looking Backward's first British edition, published by William Reeves in 1889; it is now part of the Grey collection at Auckland City Library. Alexander Turnbull owned the $19^{\text {th }}$ edition put out by Reeves; the Alexander Turnbull Library also has two local editions, from Whitcombe and Tombs in Christchurch (1890) and James Horsburgh in Dunedin (1891). Otago University has an 1890 Melbourne edition of Looking Backward while the Dunedin Public Library's collection has the Dunedin edition. Victoria University of Wellington, as well as having a copy of the Christchurch edition, has a 1920 paper edition prepared by Ernest Judd, a leader of the Socialist Labor Party in Sydney. It is inscribed "To Grandma, 1938", a sign of the book's continuing audience and circulation through the first decades of the twentieth century. No comparable popular editions are held for News from Nowhere: the Alexander Turnbull Library and Otago University both bought the 1891 Reeves and Turner edition (Alexander Turnbull's bookplate is on the cover of the ATL holding) and the 1892 Kelmscott Press edition. Victoria University's copy of the Reeves and Turner edition was a donation from Sir Thomas Easterfield in 1949. These are fine books possessed by 'bookmen', in other words, not Utopian contenders in public debate.

${ }^{3}$ The anecdote was printed in the Auckland Star, $6^{\text {th }}$ February 1890 , the Poverty Bay Herald, $11^{\text {th }}$ February 1890 and the Oamaru Mail, $21^{\text {st }}$ February 1890.

${ }^{4}$ The advertisement is in loose pages of typescript in the Roth Papers, ATL 94-10615 . 
${ }^{5}$ I draw here on Francis Shor's valuable work.

6 'Looking Forward' was reprinted in the Hawkes Bay Herald, Otago Daily Times, and Thames Advertiser in November and December 1889.

7 These details are from the Hawera Star, $3^{\text {rd }}$ March 1900; Evening Post, $13^{\text {th }}$ September 1923; and Truth, $16^{\text {th }}$ October 1909. Reports on Looking Backward's sales abroad include those in the Wanganui Herald, $26^{\text {th }}$ February 1890, the North Otago Times, $5^{\text {th }}$ March 1890 , and the Ashburton Guardian, $11^{\text {th }}$ March 1890 . The Thames Star's 'Brevities' column, $6^{\text {th }}$ June 1890 , speculated on Bellamy's personal wealth.

${ }^{8}$ Otago Daily Times, 26 $6^{\text {th }}$ October 1889; Otago Daily Times, $12^{\text {th }}$ March 1890. Reports of meetings are from the Ashburton Guardian, $13^{\text {th }}$ May 1890 , the Wanganui Herald, $1^{\text {st }}$ July 1890 , the Evening Post, $10^{\text {th }}$ June 1890 . Other meetings fusing literary and political questions in their discussion of Looking Backwards included those of the Thames Literary and Debating Society (reported in the Thames Star $9^{\text {th }}$ June 1891), the Union Literary Society (reported in the Poverty Bay Herald, 12 $2^{\text {th }}$ September 1890), and the Wesleyan Church (Northern Advocate, 23th August 1890). Rev. E. H. Gulliver gave his farewell address on Looking Backward, with his speech reported in the New Zealand Herald, 20 ${ }^{\text {th }}$ May 1890. The 'Local Gossip' column in the same paper on the $24^{\text {th }}$ May mentioned Bellamy's 'trashy book' and Gulliver's account. The Spiritualists' Association meeting is reported in the Evening Post, $2^{\text {nd }}$ May 1890.

9 'the social topsy-turvydom outlined in Looking Backward' (2) may be coming to pass, the Tupeka Times $16^{\text {th }}$ November 1892 editorialised, with reference to the 'mob rule' of the 'half holiday movement in Dunedin.' The Bruce Herald $23^{\text {rd }}$ May 1890 denounced this 'excessively stupid book' for the same reasons. James Allen's speechand its allusions to Looking Backward-was reported in the Otago Daily Times, $13^{\text {th }}$ June $1890,3$.

${ }^{10}$ Papers Past, the National Library of New Zealand's project of digitising New Zealand newspapers and periodicals from 1839 to 1945 , can be found here: http://paperspast.natlib.govt.nz/cgi-bin/paperspast . Some three million pages of newspaper are already digitised. I consulted this collection in May 2014. As new collections of newspapers are being digitised each month, the figures in this essay remain a sample and not a precise measure of the reception of Bellamy or Morris.

${ }^{11}$ On Josephs and his bookselling see Jared Davidson's excellent Sewing Freedom. Joseph's advertisements listing News from Nowhere are in the Maoriland Worker through May, June and July 1912. The Maoriland Worker Printery runs its advertisements listing News from Nowhere through 1912, 1914, twice in 1915 and once in 1918. It was the Social Democratic Party, Palmerston North branch, who advertised Morris as 'literature for propaganda' (12 ${ }^{\text {th }}$ December 1915).

${ }^{12}$ For example, Arthur McArthy wrote to the Otago Daily Times, $9^{\text {th }}$ May 1908: 'those who would know somewhat of the ideals of Socialists let them read Morris' News from Nowhere and H. G. Wells' In the Days of the Comet. They will find either of these quite as interesting as any ordinary novel, and will gain an insight into the ideal of Socialism at the same time' (5). The Timaru Herald, $1^{\text {st }}$ October 1901, 4 found in News from Nowhere an example of Anarchism that 'puts before us the ideals of this school.' 
${ }^{13}$ Roth Papers, ATL 94-106-15. The letter is dated $3^{\text {rd }}$ October 1931. The booklist is dated 1929.

${ }^{14}$ Nash's essay competition and its reading list are in Maoriland Worker, $21^{\text {st }}$ January 1914, 4. The Post Bag is from $6^{\text {th }}$ September 1916, 4. The Worker ran advertisements listing Looking Backward as socialist literature in 1913, 1919 and 1920.

${ }^{15}$ The constitution and society letterhead are to be found in the Alexander Scott collection, ATL 21-209.

${ }^{16}$ There is no reference to News from Nowhere in the papers of the William Morris Group, ATL MS Papers 7202-041. 